\title{
PD1/PD-L1 inhibition as a potential radiosensitizer in head and neck squamous cell carcinoma: a case report
}

\author{
Misako Nagasaka ${ }^{1}$, Mark Zaki ${ }^{2}$, Harold Kim², S. Naweed Raza ${ }^{3}$, George Yoo ${ }^{3}$, Ho-sheng Lin $^{3}$ and Ammar Sukari ${ }^{\text {* }}$
}

\begin{abstract}
Background: Immunotherapy targeting the checkpoint PD1 (programmed cell death protein 1) or PDL1 (programmed death ligand 1) has led to advances in the treatment of melanoma and non-small cell lung cancer (NSCLC). The use of such therapies has also been introduced into the treatment of other malignancies, including head and neck cancer. The combined effects of checkpoint inhibitors and anti-PD1(L1) antibodies and radiation therapy have not yet been sufficiently investigated.
\end{abstract}

Case presentation: We report a case of locally relapsed non-resectable oral cavity squamous cell carcinoma, with excellent local control after pembrolizumab (MK3475) followed by radiotherapy.

Conclusion: T cell activation induced by checkpoint inhibition may dramatically improve tumor response to radiation. More data are needed to identify the toxicity and efficacy of sequential or concurrent checkpoint inhibitors and radiotherapy.

Keywords: PD1/PDL1 inhibitor, Oral cancer, Radiation therapy

\section{Background}

The development of immunotherapy targeting the PD1/PDL1 checkpoint inhibition pathway represents considerable progress in the treatment of many cancer types. Pembrolizumab is a humanized monoclonal antibody that blocks the interaction of PD-1 with its ligands, PD-L1 and PD-L2. It is FDA approved for the treatment of melanoma and NSCLC and was recently granted accelerated approval for the treatment of recurrent or metastatic head and neck squamous cell carcinoma in patients with disease progression on or after platinum-containing chemotherapy [1]. Little is known regarding the effects of radiation following PD1 inhibition. We report a case of a patient who experienced excellent local control with immunotherapy followed by radiation therapy for relapsed oral cavity cancer.

\footnotetext{
* Correspondence: sukaria@karmanos.org

${ }^{1}$ Department of Oncology, Barbara Ann Karmanos Cancer Institute, Wayne

State University School of Medicine, Detroit, MI, USA

Full list of author information is available at the end of the article
}

\section{Case presentation}

A 66 year old woman with floor of mouth squamous cell carcinoma (SCC) presented to our institution after her second relapse. Originally diagnosed in 2006, she had undergone a composite resection with a flap reconstruction and bilateral neck dissections followed by post-surgical adjuvant radiotherapy for stage IVa (T4aNOM0) disease. Immunohistochemistry (IHC) staining for p16 was negative. In May of 2009, a resectable locoregional recurrence was detected and consequently treated with a composite resection utilizing a pectoralis flap reconstruction. In November of 2013, she presented with a second non-resectable locoregional relapse. She received carboplatin and paclitaxel for 4 cycles with a partial response (PR) after 2 cycles. The patient subsequently developed regional progression and was treated with weekly methotrexate and cetuximab and she achieved stable disease (SD) for 6 months. Later, she progressed locally and was enrolled into a trial utilizing single agent pembrolizumab. She had SD for 6 cycles (Fig. 1), and then 


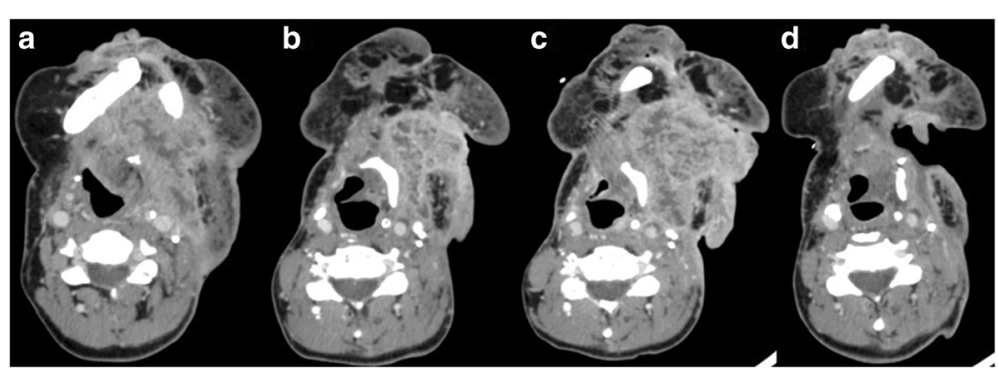

Fig. 1 Change in largest dimensions of neck mass on CT scans over treatment period. a Prior to pembrolizumab. $8.8 \times 5.9 \mathrm{~cm}$. $\mathbf{b}$ Best response to pembrolizumab. $6 \times 4 \mathrm{~cm}$. c Progression on pembrolizumab. $7.1 \times 7.2 \mathrm{~cm}$. d Post radiation $5.9 \times 3.4 \mathrm{~cm}$

suffered from local progression with a significant increase in the size of her neck mass, with painful ulceration and bleeding. Pembrolizumab was therefore discontinued. At this time restaging studies revealed no evidence of distant metastasis. She required multiple transfusions secondary to tumor hemorrhage and as a result was treated palliatively with radiation therapy to a total dose of 30 Gy directed at the mass. The patient experienced an excellent clinical response. Bleeding had resolved (Fig. 2) and her pain had greatly improved. A significant radiographic response was also noted on computed tomography (CT) scan, with tumor dimensions decreasing by $60 \%$, from $7.1 \times$ $7.2 \mathrm{~cm}$ pre-radiation, to $5.9 \times 3.4 \mathrm{~cm}, 6$ weeks postradiation.

\section{Discussion}

\section{Pembrolizumab in head and neck cancer}

The strongest available data for checkpoint inhibitors in head and neck SCC are from an expansion cohort of a phase Ib study (KEYNOTE-012), utilizing pembrolizumab in the recurrent/metastatic setting (Table 1). One hundred and ninety-two patients were enrolled. Confirmed objective response rate (ORR) was $17.7 \%$ (95\% CI, 12.6-23.9 \%; 7 complete responses [CRs], 27 PRs). Thirty three (17\%) patients achieved stable disease. ORR was seen in $21.9 \%$ (95\% CI, 12.5-34.0 \%) of HPV (human papilloma virus) positive and in $15.9 \%$ (95\% CI, 10.0-23.4 \%) of HPV negative patients. The median overall survival (OS) was 8.5 months $(95 \% \mathrm{CI}$,
6.5-10.5). These were patients who were heavily pretreated and a majority of them had more than two lines of previous therapy. Treatment-related adverse events (TRAEs) occurred in 122 (64 \%) patients; 23 (12\%) patients had a grade 3-4 TRAE [2].

\section{Radiation therapy and immunotherapy}

The effects of radiation following PD1 inhibition are unknown. Current data come from the concurrent administration of immune checkpoint inhibitors with radiotherapy. Radiation is thought to enhance antitumor immune responses by causing inflammatory cell death, major histocompatibility complex (MHC) I upregulation, and release of antigens that are taken up by dendritic cells [3]. Mouse models have shown increased PD-L1 expression in tumors following irradiation [4]. The abscopal effect; or the phenomenon in which tumor regression occurs at sites distant from the site of radiation, has been documented in melanoma and NSCLC patients who underwent radiation with ipilimumab, a CTLA-4 (cytotoxic T-lymphocyte-associated protein 4) checkpoint inhibitors [5, 6]. This further supports the concept of synergistic activity between checkpoint inhibitors and radiation.

Identifying the most beneficial timing for combined radiotherapy and immunotherapy remains a challenge. If radiation is given prior to, or concurrently with immunotherapy, immunotherapy may be more effective with tumor specific antigens originally generated by radiotherapy. On the other hand, if immunotherapy is

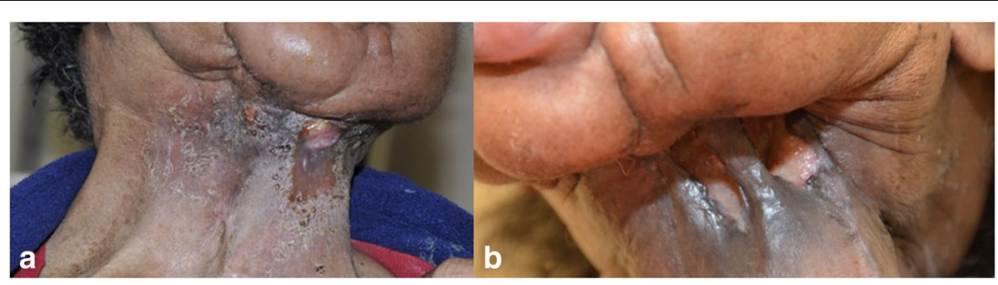

Fig. 2 Appearance of neck mass post pembrolizumab and radiation therapy. a Local control was achieved after 6 cycles of single agent pembrolizumab therapy. $\mathbf{b}$ The bleeding mass resolved after radiation therapy 
Table 1 Ongoing trials on PD1 inhibitors in HNSCC

\begin{tabular}{|c|c|c|c|c|c|}
\hline $\begin{array}{l}\text { Abbreviated Trial } \\
\text { Name/NCT\# }\end{array}$ & Phase & Agent(s) & Study population & $\begin{array}{l}\text { Findings/Expected } \\
\text { Primary Endpoint }\end{array}$ & Safety \\
\hline $\begin{array}{l}\text { KEYNOTE-012/ } \\
\text { NCT01848834 } \\
\text { Data updated } \\
\text { from ASCO } \\
2016\end{array}$ & $\mathrm{Ib}$ & Pembrolizumab & Recurrent/metastatic HNSCC & $\begin{array}{l}\text { ORR } 17.7 \% \text { (95 \% Cl, } \\
12.6-23.9 \% \text {; } 7 \text { CRs, } 27 \mathrm{PRs}) \\
\text { HPV+ } 21.9 \% \text {, HPV- } 15.9 \% \text {. } \\
\text { Median OS } 8.5 \text { mo ( } 95 \% \mathrm{Cl} \text {, } \\
\text { 6.5-10.5). }\end{array}$ & $\begin{array}{l}\text { Grade } 3-4 ; 12 \% \\
\text { No treatment related deaths }\end{array}$ \\
\hline $\begin{array}{l}\text { KEYNOTE-055/ } \\
\text { NCT02255097 } \\
\text { Presented } \\
\text { ASCO } 2016\end{array}$ & $\|$ & Pembrolizumab & $\begin{array}{l}\text { Recurrent/metastatic HNSCC, } \\
\text { progressed on platinum and } \\
\text { cetuximab }\end{array}$ & $\begin{array}{l}\text { ORR } 18 \%(95 \% \mathrm{Cl} 9-31) \\
\text { HPV }+22 \%, \mathrm{HPV}-16 \% \\
\text { SD } 18 \%\end{array}$ & Grade $3-5 ; 20 \%$ \\
\hline $\begin{array}{l}\text { KEYNOTE-040/ } \\
\text { NCT02252042 } \\
\text { Ongoing }\end{array}$ & III & $\begin{array}{l}\text { Pembrolizumab VS } \\
\text { Chemotherapy } \\
\text { (methotrexate, } \\
\text { docetaxel or cetuximab) }\end{array}$ & Recurrent/metastatic HNSCC & $\begin{array}{l}\text { PFS } \\
\text { OS }\end{array}$ & \\
\hline $\begin{array}{l}\text { KEYNOTE-048/ } \\
\text { NCT02358031 } \\
\text { Ongoing }\end{array}$ & III & $\begin{array}{l}\text { Pembrolizumab VS P } \\
\text { embro + cis/carbo + 5FU } \\
\text { VS Cetuximab + cis/carbo } \\
+5 \mathrm{FU}\end{array}$ & $\begin{array}{l}\text { First line treatment for recurrent/ } \\
\text { metastatic HNSCC }\end{array}$ & PFS & \\
\hline $\begin{array}{l}\text { CheckMate141/ } \\
\text { NCT02105636 } \\
\text { Presented } \\
\text { AACR } 2016\end{array}$ & III & $\begin{array}{l}\text { Nivolumab VS Chemo } \\
\text { (methotrexate, docetaxel } \\
\text { or cetuximab) }\end{array}$ & Recurrent/metastatic HNSCC & $\begin{array}{l}1 \text { year OS; nivo } 36 \% \text {, chemo } \\
16.6 \% \\
\text { Median OS; nivo } 7.5 \text { mon, } \\
\text { chemo } 5.1 \text { months }\end{array}$ & \\
\hline
\end{tabular}

delivered before radiotherapy, the active immune microenvironment may maximize radiation efficacy [7]. In the present case, radiotherapy was given immediately following discontinuation of pembrolizumab in an attempt to control bleeding. The excellent response seen in the present case may be attributed from the synergistic effect of pembrolizumab.

One possible disadvantage of the concurrent administration of checkpoint inhibitors and radiation is the potential for added toxicities. In the present case, it is probable that the risk of adverse events (AE) was mitigated by the sequential delivery of therapy. In an analysis of 29 unresectable/metastatic melanoma patients who underwent radiation while receiving ipilimumab, the authors concluded that concurrent therapy was not associated with higher than expected rates of AEs, nor did it invalidate the palliative effects of radiation or survival benefits from ipilimumab $[8,9]$.

Several clinical trials are evaluating combined radiotherapy and checkpoint inhibitors in head and neck SCC (Table 2). The phase Ib study of cetuximab, ipilimumab and intensity modulated radiation therapy (IMRT) in stage III-IVa HPV+ oropharyngeal SCC (NCT01935921) and the phase II study of concurrent versus sequential pembrolizumab, cisplatin and IMRT in stage III-IVb head and neck SCC are currently accruing patients (NCT0277385).

\section{Conclusion}

As we await further data, a trial of radiation following immunotherapy could be considered for disease control in selected patients.

Table 2 Ongoing studies on PD1 inhibitors and radiation therapy in HNSCC

\begin{tabular}{|c|c|c|c|c|}
\hline $\begin{array}{l}\text { Abbreviated Trial Name/ } \\
\text { NCT\# }\end{array}$ & Phase & Agent(s) & Study population & Expected Primary Endpoint \\
\hline NCT01935921 & $\mathrm{lb}$ & Cetuximab, ipilimumab and IMRT & $\begin{array}{l}\text { stage III-IVa } \\
\text { HPV+ OPSCC }\end{array}$ & Dose limiting toxicities (DLT) \\
\hline $\begin{array}{l}\text { RTOG } 3504 \\
\text { NCT02764593 }\end{array}$ & $\begin{array}{l}\text { III w/phase } \\
\text { I lead in }\end{array}$ & Nivolumab and cisplatin CRT & $\begin{array}{l}\text { stage III-IV, intermediate to high risk } \\
\text { HNSCC }\end{array}$ & DLT for phase I \\
\hline NCT02777385 & $\|$ & $\begin{array}{l}\text { Concurrent vs sequential pembro, } \\
\text { cisplatin and IMRT }\end{array}$ & $\begin{array}{l}\text { stage III-IVb } \\
\text { HNSCC }\end{array}$ & $\begin{array}{l}1 \text { year PFS } \\
1 \text { year failure rate } \\
\text { Acute toxicity rates }\end{array}$ \\
\hline $\begin{array}{l}\text { HN003 } \\
\text { NCT02775812 }\end{array}$ & I & $\begin{array}{l}\text { Adjuvant pembro, cisplatin and } \\
\text { IMRT }\end{array}$ & high risk stage III-IV HSNCC & DLT \\
\hline NCT02641093 & $\|$ & $\begin{array}{l}\text { Adjuvant pembro, cisplatin and } \\
\text { IMRT }\end{array}$ & high risk stage III-IV HSNCC & $\begin{array}{l}\text { Treatment related adverse events } \\
\text { (TRAE) } \\
\text { Disease free survival (DFS) }\end{array}$ \\
\hline
\end{tabular}




\section{Acknowledgements}

We indicate here that the result of this study was accepted for an oral presentation at the AHNS 9th International Conference on Head and Neck Cancer. The authors have not published or submitted any related papers from the same study. We thank our patients, their families and our colleagues at Karmanos Cancer Institute who supported us in the preparation of this manuscript. All authors read and approved the final manuscript.

\section{Abbreviation}

CR: Complete response; CT: Computed tomography; HPV: Human papilloma virus; IMRT: Intensity modulated radiation therapy; MHC: Major histocompatibility complex; NSCLC: Non-small cell lung cancer; ORR: Objective response rate; OS: Overall survival; PD-1: Programmed cell death protein 1; PD-L1: Programmed death ligand 1; PR: Partial response; SCC: Squamous cell carcinoma; SD: Stable disease; TRAE: Treatment-related adverse events

\section{Funding}

The authors did not receive any grants or other financial support for the preparation of this manuscript.

\section{Authors' contributions}

MN and AS contributed to the planning, organization, data collection and writing of the manuscript. AS is also the treating oncologist for this case and is the corresponding author for this manuscript. MZ, HK, SNR, GY and $\mathrm{HL}$ all treated the patient, reviewed the manuscript and provided critical edits. All authors read and approved the final manuscript.

\section{Competing interests}

The authors declare that they have no competing interests.

\section{Consent for publication}

Consent for treatment and publication was obtained from the patient herself. Availability of data and material: Data sharing not applicable to this article as no datasets were generated or analyzed during the current study.

\section{Ethics approval and consent to participate}

Need for approval was waived by the Karmanos Protocol Review and Monitoring Committee.

\section{Author details}

'Department of Oncology, Barbara Ann Karmanos Cancer Institute, Wayne State University School of Medicine, Detroit, MI, USA. ${ }^{2}$ Division of Radiation Oncology, Department of Oncology, Barbara Ann Karmanos Cancer Center, Wayne State University School of Medicine, Detroit, MI, USA. ${ }^{3}$ Department of Otolaryngology-Head and Neck Surgery, Barbara Ann Karmanos Cancer Institute, Wayne State University School of Medicine, Detroit, MI, USA.

Received: 24 August 2016 Accepted: 1 November 2016

Published online: 15 November 2016

\section{References}

1. U.S. Food and Drug Administration. Approved Drugs: pembrolizumab (KEYTRUDA). http://www.fda.gov/Drugs/InformationOnDrugs/ ApprovedDrugs/ucm515627.htm. Accessed 23 Sept 2016

2. Seiwert TY, Burtness B, Mehra R, et al. Safety and clinical activity of pembrolizumab for treatment of recurrent or metastatic squamous cell carcinoma of the head and neck (KEYNOTE-012): an open-label, multicentre, phase 1b trial. Lancet Oncol. 2016;17:956-65.

3. Mehra R, Seiwert TY, Mahipalet A, et. al. Efficacy and safety of pembrolizumab in recurrent/metastatic head and neck squamous cell carcinoma (R/M HNSCC): pooled analyses after long-term follow-up in KEYNOTE-012. J Clin Oncol. 2016;34 (suppl; abstr 6012).

4. Tang $\mathrm{C}$, Wang $\mathrm{X}$, Soh $\mathrm{H}$, et al. Combining radiation and immunotherapy: a new systemic therapy for solid tumors? Cancer Immunol Res. 2014;2:831-8.

5. Deng L, Liang H, Burnette B, et al. Irradiation and anti-PD-L1 treatment synergistically promote antitumor immunity in mice. J Clin Invest. 2014; 124:687-95
6. Postow MA, Callahan MK, Barker CA, et al. Immunologic correlates of the abscopal effect in a patient with melanoma. N Engl J Med. 2012;366(10): $925-31$.

7. Golden EB, Demaria S, Schiff PB, et al. An abscopal response to radiation and ipilimumab in a patient with metastatic non-small cell lung cancer. Cancer Immunol Res. 2013;1(6):365-72.

8. Teng F, Kong L, Meng $\mathrm{X}$, et al. Radiotherapy combined with immune checkpoint blockade immunotherapy: achievements and challenges. Cancer Lett. 2015:365:23-9.

9. Barker CA, Postow MA, Khan SA, et al. Concurrent radiation therapy and ipilimumab immunotherapy for patients with melanoma. Cancer Immunol Res. 2013;1(2):92-8.

\section{Submit your next manuscript to BioMed Central and we will help you at every step:}

- We accept pre-submission inquiries

- Our selector tool helps you to find the most relevant journal

- We provide round the clock customer support

- Convenient online submission

- Thorough peer review

- Inclusion in PubMed and all major indexing services

- Maximum visibility for your research

Submit your manuscript at www.biomedcentral.com/submit
Biomed Central 